\title{
Phytochemical screening and evaluation of antioxidant and antibacterial activities of seeds and pods extracts of Calycotome villosa subsp. Intermedia
}

\author{
Aouicha Elkhamlichi ${ }^{\mathrm{a}}$, Hanane El Hajaji ${ }^{\mathrm{a}}$, Hassan Faraj ${ }^{\mathrm{b}}$, Anouar Alami ${ }^{\mathrm{b}}$, Brahim El Bali ${ }^{\mathrm{a}}$, Mohammed Lachkar ${ }^{\mathrm{a}^{*}}$ \\ ${ }^{a}$ Engineering Laboratory of Organometallic and Molecular Materials (CNRST-URAC19), Faculty of Sciences, Sidi Mohammed Ben Abdellah University, \\ Po. Box 1796 (Atlas), $30000 \mathrm{Fez}$, Morocco. ${ }^{\text {b}}$ Laboratory of Organic Chemistry, Faculty of Sciences, Sidi Mohammed Ben Abdellah University, Po. Box \\ 1796 (Atlas), $30000 \mathrm{Fez}$, Morocco.
}

\begin{tabular}{l} 
ARTICLE INFO \\
\hline Article history: \\
Received on: $28 / 01 / 2017$ \\
Accepted on: $26 / 03 / 2017$ \\
Available online: $30 / 04 / 2017$ \\
\hline Key words: \\
Calycotome villosa subsp. \\
intermedia, antioxidant \\
activity, total flavonoids \\
contents, total phenolic \\
contents, antibacterial \\
activity.
\end{tabular}

\begin{abstract}
In the present study, antioxidant potential of the methanol and the ethyl acetate extracts of the seeds and pods of Calycotome villosa subsp. intermedia were evaluated by using 1,1-diphenyl-2-picrylhydrazyl (DPPH) scavenging assay, reducing power and total antioxidant capacity. In DPPH scavenging assay, the $\mathrm{IC}_{50}$ value of the methanolic extract of seeds was found to be $0.20 \mathrm{mg} / \mathrm{mL}$, the standard reference value for butylatedhydroxytoluene (BHT) is $0.19 \mathrm{mg} / \mathrm{mL}$. Total antioxidant activity was also found to increase in a dose dependent manner. Moreover, Calycotome villosa extract showed strong reducing power. The total phenolic content in the extracts was determined using Folin-Ciocalteu reagent and their amounts ranged between 173.37 \pm 0.02 to $332.23 \pm 0.01 \mathrm{mg} \mathrm{GA}$ (Gallic Acid)/g of dry extract. The concentrations of flavonoids in the extracts varied from $5.02 \pm 0.03$ to $66.45 \pm 0.01 \mathrm{Qu}$ (Quercetin)/g of dry extract. Ethyl acetate extract of seeds of Calycotome villos a showed the highest phenolic, flavonoids concentration and the strongest antioxidant activity. The high contents of phenolic compounds indicated that these compounds contribute to the antioxidant activity. Furthermore, all extracts showed good antibacterial activity against Escherichia coli. Calycotome villosa subsp. intermedia can be regarded as promising candidate for natural plant sources of antioxidants with high value.
\end{abstract}

\section{INTRODUCTION}

Antioxidant research is an important topic in the medical field as well as in the food industry. Many plants, particularly medicinal ones, have been extensively studied for their antioxidant activity in recent decades. Antioxidants from aromatic, spicy, medicinal, and other plants were studied to develop natural antioxidant formulations for food, cosmetic, and other applications (Miliauskas et al., 2004). It is believed that an increased intake of food rich in natural antioxidants is associated with lower risks of degenerative diseases, particularly

\footnotetext{
* Corresponding Author

Mohammed Lachkar, Engineering Laboratory of Organometallic and Molecular Materials (CNRST-URAC19), Faculty of Sciences, Sidi Mohammed Ben Abdellah University, Po. Box 1796 (Atlas), 30000 Fez, Morocco.Email: lachkar.mohammed @gmail.com
}

cardiovascular diseases and cancer (Perez-Jimenez et al., 2008). There are three major classes of plant chemicals: terpenoids, phenolic, and alkaloids (Harborne, 1999). Among these three groups, phenolic compounds are the most important for dietary applications and the most extensively researched (King and Young, 1999). Phenolic compounds include phenolic acids (hydroxybenzoic and hydroxycinnamic acids), polyphenols (hydrolyzable and condensed tannins), and flavonoids. These compounds can scavenge excess free radicals and effectively reduce oxidative stress, which protect plants, fruits, and vegetables and protect DNA, protein and lipids in the human body from oxidative damage. They have been used as antioxidants by humans, thus preventing diseases from being induced. Finding new and safe antioxidants from natural sources is of great interest for applications as natural antioxidants, functional foods, and neutraceuticals. 
Phytochemical screening is one of the methods that have been used to explore antioxidant compounds in plants. Calycotome villosa, a genus of flowering plants in the legume family (Leguminosae), grows mostly in cool places, and is very common in the Mediterranean area (Gibbs, 1968; Tutin, 1972). However, Calycotome villosa (Poiret) Link subsp. intermedia (C. Presl) Quezel and Santa, a $50-150 \mathrm{~cm}$ spiny shrub, grows especially in the north of Africa and Spain (Greuter et al., 1989). In Morocco this plant settles in degraded areas, forming an abundant shrub stratum (Bonin, 1994). A survey of the bibliography showed us no uses in the Moroccan folk medicine are known for this species. Medicinal uses have been reported only for Calycotome villosa (Poiret) Link as antitumoral agent (Hartwell, 1982) and for the treatment of furuncle, cutaneous abscess and chilblain in the Sicilian folk medicine (Lentini et al., 1993). In previous phytochemical studies of Calycotome villosa subsp. intermedia, we have reported the isolation and characterization of flavone glucosides from the leaves and flowers (El Antri et al., 2004a), flavonols from the seeds (El Antri et al., 2010), tetrahydroisoquinoline alkaloids, isoquinoline-N-oxide and dihydroisoquinoline-N-oxide alkaloids, and a paraben derivative from the seeds (El Antri et al., 2004b, 2004c, Elkhamlichi et al., 2014). The aims of this study were to screen for phytochemical constituents, determine the total phenolic and flavonoid contents, and evaluate in vitro antioxidant activity of seeds and pods extracts of Calycotome villosa subsp. intermedia. Three different antioxidant test systems were performed: DPPH, reducing power and total antioxidant capacity assays. Antibacterial proprieties were also examined.

\section{MATERIAL AND METHODS}

\section{Plant material}

Seeds and pods of Calycotome villosa subsp. intermedia were collected from the aerial part of the plant in June 2011 and again in June 2012 from area of Sefrou (Morocco). The plant was identified by Dr. Abdeslam Ennabili (Sidi Mohammed Ben Abdellah University, Fez, Morocco). A voucher specimen ( ${ }^{\circ}$ EN008) has been deposited at the herbarium of the "Institut National des Plantes Médicinales et Aromatiques", Sidi Mohammed Ben Abdellah University, Taounate, Morocco.

\section{Preparation of the extracts}

The seeds and pods were used just after harvest and they were crushed with a grinder. The powdered seeds (154.13 g) and pods (68.16 g) of Calycotome villosa subsp. intermedia were first extracted with hexane for $24 \mathrm{~h}$ to remove chlorophylls and fats, then with methanol for $48 \mathrm{~h}$ using a Soxhlet apparatus. The methanolic solution was evaporated to dryness and the resulting crude seeds extract (18.3 g) and pods extract (13.08 g) was dissolved in a $5 \%$ hydrochloric acid solution. The residue was solubilized in methanol; the methanol residue which is not soluble in methanol was dissolved in ethyl acetate and evaporated under reduced pressure by a rotary evaporator to give respectively $3.93 \mathrm{~g}$ of the crude extract of seeds and $1.87 \mathrm{~g}$ of the crude extract of pods.

\section{Phytochemical screening}

Phytochemical screening to detect the presence of bioactive agents was performed by standard procedures (De et al., 2010). After the addition of specific reagents to the solution, the tests were detected by visual observation of color change or by precipitate formation.

\section{Total phenolic contents}

The total phenolic contents were determined spectrophotometrically using the Folin-Ciocalteu reagent. This reagent based on the Slinkard and Singleton method (Slinkard and Singleton, 1977) and the early work of Singleton and Rossi (Singleton and Rossi, 1965) is a colorimetric oxidation/reduction method for phenolic compounds. Briefly, extracts were reacted with Folin-Ciocalteu reagent and then neutralized with sodium carbonate solution (25\%). After $2 \mathrm{~h}$, the absorbance of the resulting solution was measured at $765 \mathrm{~nm}$. The concentrations of phenolic compounds were calculated according to the following equation that was obtained from the standard as gallic acid graph:

Absorbance $=0.0007$ gallic acid $(\mu \mathrm{g})+0.0642\left(\mathrm{R}^{2}=0.9964\right)$

All tests were carried out in triplicate and the results are given as gallic acid equivalents (GAE) per $g$ of dry extract.

\section{Total flavonoid contents}

Total flavonoid contents were determined using the Dowd method as adapted by Arvouet-Grand (Arvouet-Grand et al., 1994), $1 \mathrm{~mL}$ of $2 \%$ aluminium trichloride $\left(\mathrm{AlCl}_{3}\right)$ in methanol was mixed with the same volume of the methanolic extracts $(2000$ $\mu \mathrm{g})$. Absorption readings at $415 \mathrm{~nm}$ were taken after $10 \mathrm{~min}$ against a blank sample consisting of a $1 \mathrm{~mL}$ extract solution with 1 $\mathrm{mL}$ methanol without $\mathrm{AlCl}_{3}$. The concentrations of flavonoid compounds were calculated according to the following equation that was obtained from the standard quercetin graph:

Absorbance $=0.0333$ quercetin $(\mu \mathrm{g})+0.0231\left(\mathrm{R}^{2}=0.9961\right)$

\section{Antioxidant studies}

In the present study, three commonly used antioxidant evaluation methods such as DPPH radical scavenging activity, reducing power assay and phosphomolybdenum method were chosen to determine the antioxidant potential of seeds and pods of Calycotome villosa subsp. Intermedia.

\section{Determination of free radical scavenging activity by $D P P H$ method}

The DPPH (1,1-diphenyl-2-picrylhydrazyl) assay is one of the most commonly employed methods because, in general terms, it is simple, efficient and inexpensive. The original method was developed by Blois (Blois, 1958) and, with the modifications introduced by Brand-Williams, Cuvelier, and Berset (BrandWilliams, 1995), it is widely used as a reference point (Bondet et al., 1997; Chen et al., 2013). The results are normally expressed as 
Efficient Concentration $\left(\mathrm{EC}_{50}\right)$ otherwise called the $\mathrm{IC}_{50}$ value, which is defined as the amount of sample necessary to decrease the initial DPPH concentration by $50 \%$. The parameter $\mathrm{IC}_{50}$ was introduced by Brand-Williams (Brand-Williams, 1995), Molyneux (Molyneux, 2004), Kedare and Singh (Kedare and Singh, 2011), and it is very useful for comparing results because it is independent of the sample concentration. Many authors use the antiradical power (ARP) parameter, which is defined as the reciprocal of $\mathrm{IC}_{50}: \mathrm{ARP}=1 / \mathrm{IC}_{50}$. The $\mathrm{DPPH}$ assay was employed to test the antioxidant potential of the ethyl acetate and the methanolic extracts of the seeds and pods of Calycotome villosa subsp. intermedia. Briefly, $100 \mu \mathrm{L}$ of various concentrations of the extract in methanol was added to $10 \mathrm{~mL}$ of a methanol solution of DPPH $\left(1.014 \times 10^{-2} \mathrm{M}\right)$. The mixture was vigorously shaken and then allowed to stand at room temperature for $30 \mathrm{~min}$ in the dark. The absorbance of the mixture was measured at $517 \mathrm{~nm}$ by using a double-beam UV-visible Camspec M550 spectrophotometer. A mixture of $100 \mu \mathrm{L}$ of methanol and $10 \mathrm{~mL}$ of methanol solution of DPPH was used as the control. The scavenging activity on the DPPH radical was expressed as inhibition percentage using the following equation:

$\%$ Inhibition $=\left[\left(\mathrm{Abs}_{\text {control }}-\mathrm{Abs}_{\text {sample }}\right) / \mathrm{Abs}_{\text {control }}\right] \times 100$ (Blois, 1958)

Butylatedhydroxytoluene (BHT) was used as positive control. The tests were carried out in triplicate. The extract concentration providing $50 \%$ inhibition $\left(\mathrm{IC}_{50}\right)$ was calculated from the graph of inhibition percentage plotted against extract concentration (4.0, 2.0, 1.0, 0.5 and 0.25 mg/L) (Viturro, et al., 1999).

\section{Total antioxidant capacity (TAC)}

The total antioxidant capacity of the methanol extract and the ethyl acetate were evaluated by the phosphomolybdenum method according to the procedure described by Prieto (Prieto et al., 1999). The assay is based on the reduction of Mo(VI) to $\mathrm{Mo}(\mathrm{V})$ by the extract and subsequent formation of green phosphate/Mo(V) complex at acid pH. A $0.1 \mathrm{~mL}$ extract was combined with $1 \mathrm{~mL}$ of reagent solution (0.6 M sulfuric acid, 28 $\mathrm{mM}$ sodium phosphate and $4 \mathrm{mM}$ ammonium molybdate). The test-tubes containing the reaction solution were incubated at $95^{\circ} \mathrm{C}$ for $90 \mathrm{~min}$. Then the absorbance of the solution was measured at $695 \mathrm{~nm}$ using a double-beam UV-visible Camspec M550 spectrophotometer against blank after cooling to room temperature. Methanol $(0.1 \mathrm{~mL})$ in the place of extract was used as the blank. The antioxidant activity is expressed as the number of gram equivalent of ascorbic acid. The calibration curve was prepared by mixing ascorbic $(100,50,25,12.5$ and $6.25 \mu \mathrm{g} / \mathrm{mL})$ with methanol. Methanol $(0.1 \mathrm{~mL})$ in the place of extract is used as the blank. The antioxidant activity is expressed as the number of equivalents of ascorbic acid.

\section{Ferric reducing antioxidant power (FRAP)}

The ferric reducing antioxidant power was determined according to the method previously described by Oyaizu (Oyaizu, 1986). According to this method, the reduction of $\mathrm{Fe}^{3+}$ to $\mathrm{Fe}^{2+}$ is determined by measuring the absorbance of Perl's Prussian blue complex. Briefly, different concentrations of extracts $(5-200 \mu \mathrm{g})$ in $1 \mathrm{~mL}$ of distilled water were mixed with phosphate buffer $(2.5 \mathrm{~mL}$, $0.2 \mathrm{M}, \mathrm{pH} 6.6)$ and potassium ferricyanide $\left[\mathrm{K}_{3} \mathrm{Fe}(\mathrm{CN})_{6}\right](2.5 \mathrm{~mL}, 1$ $\%)$.

The mixture was incubated at $50^{\circ} \mathrm{C}$ for $20 \mathrm{~min}$. An aliquot $(2.5 \mathrm{~mL})$ of trichloroacetic acid $(10 \%)$ was added to the mixture, which was then centrifuged at $3000 \mathrm{rpm}$ for $10 \mathrm{~min}$. The supernatant $(2.5 \mathrm{~mL})$ was mixed with distilled water $(2.5 \mathrm{~mL})$ and $\mathrm{FeCl}_{3}(0.5 \mathrm{~mL}, 0.1 \%)$ and the absorbance was measured at 700 $\mathrm{nm}$. Increased absorbance of the reaction mixture indicated increased reducing power. Ascorbic acid was used as the reference.

\section{Determination of antibacterial activity Test micro-organisms}

A total of four bacterial species were tested including Pseudomonas aeroginosa ATCC 27853, Escherichia coli ATCC 25922 (Gram-negative), Bacillus subtilis ILP 14283 and Staphylococcus aureus (Gram-positive) ATCC 25922 have been used. The strains were cultured on nutrient agar and incubated at $37^{\circ} \mathrm{C}$ for $24 \mathrm{~h}$ and were then maintained in their appropriate agar medium at $4^{\circ} \mathrm{C}$ throughout the study and used as stock cultures.

\section{Disc diffusion assay}

The antibacterial activity of the methanol extracts and ethyl acetate extracts was examined by disk-diffusion method (NCCLS, 2012) with some modifications. Briefly, bacterial strains were cultured overnight at $37^{\circ} \mathrm{C}$ on Luria-Bertani broth, and then inoculum consisting of $0.5 \mathrm{McF}$ arland was prepared in physiologic saline. Bacterial inoculum $(100 \mu \mathrm{L})$ was inoculated in Petri dishes containing a sterile Luria-Bertani Agar medium. Sterile filter paper discs $(5 \mathrm{~mm}$ diameter) were deposited on medium and impregnated with $10 \mu \mathrm{L}$ of extract solution $(20 \mathrm{mg} / \mathrm{mL}$ of DMSO to $2 \%)$.

The plates were inverted and incubated for $20 \mathrm{~h}$ at $37^{\circ} \mathrm{C}$. The control was performed with discs containing $10 \mu \mathrm{L}$ of DMSO to $2 \%$. Each experiment was performed in duplicate. Microbial inhibition was determined by measuring the diameter of the clear zone of inhibition of growth around each disc and recorded as diameter of inhibition zone in millimeter. The scale of measurement was the following (disc diameter included): $\geq 20$ $\mathrm{mm}$ : zone of inhibition is strongly inhibitory; <20-12 mm: zone of inhibition is moderately/mildly inhibitory; and < $12 \mathrm{~mm}$ is no inhibitory (Espina et al., 2011).

\section{Statistical analysis}

All analyses were done at least in triplicate, and these values were then presented as average values along with their standard derivations. Statistical comparisons were performed with one way analysis of variance, and $p$ values $<0.05$ were regarded as significant. Correlation coefficients $(\mathrm{R})$ to determine the relationship among TAC assay, TPC and TFC were calculated using MS Excel software (CORREL statistical function). 


\section{RESULTS AND DISCUSSION}

\section{Phytochemical screening}

The results of phytochemical screening of seeds and pods for the methanol and ethyl acetate extract of Calycotome villosa subsp. intermedia are given in the Table 1. The cyanidin test for flavonoids showed the presence of flavones in methanolic extract and the flavonols in ethyl acetate extract which is confirmed by a previous study, two flavonols no glycosylated were isolated from the seeds (El Antri et al., 2010). In pods extracts, phytochemical analysis revealed the presence of flavones from the methanolic and ethyl acetate extracts, the tannins with high presence in ethyl acetate. The methanolic and ethyl acetate extracts doesn't contain the alkaloids which were dissolved in a $5 \%$ hydrochloric acid solution. The saponins were not detected in these extracts.

Table 1: Phytochemicals detected in extracts of $C$. villosa seeds and pods.

\begin{tabular}{lccc}
\hline Categories & Phytochemicals & Methanol & Ethyl acetate \\
\hline \multirow{4}{*}{ Pods } & Alkaloids & - & - \\
& Flavonoids & + & + \\
& Tannins & + & + \\
\hline \multirow{4}{*}{ Seeds } & Saponins & - & - \\
& Alkaloids & - & + \\
& Flavonoids & + & + \\
\hline
\end{tabular}

Key: + for present; - for absent.

\section{Total phenolic contents}

Total phenolic and flavonoid contents and antioxidant activity in vitro were determined for methanol and ethyl acetate extracts of seeds and pods of Calycotome villosa subsp. intermedia. The results of the total phenolic content determination of the examined plant extract are presented in Table 2. The content of total phenols in different extracts, expressed as gallic acid equivalents (GA) per gram of dry extract, ranged between 173.37 \pm 0.02 to $332.23 \pm 0.01 \mathrm{mg} \mathrm{GA} / \mathrm{g}$. The highest phenolic content was found in methanol extracts (with $2 \mathrm{mg} / \mathrm{mL}$ extract concentration). The phenolic compounds are generally more soluble in polar solvents, in this research the logic was respected since the crude extract; the methanolic extracts of seeds and pods have the highest phenolic content than ethyl acetate extract.

Table 2: Total phenolic contents.

\begin{tabular}{lcc}
\hline Categories & Sample & $\begin{array}{c}\text { Total phenolic content } \\
\text { (mg GAE /g DE) }\end{array}$ \\
\hline Seeds & $\mathrm{MeOH}$ & $332.23 \pm 0.01$ \\
& EtOAc & $243.94 \pm 0.03$ \\
\hline Pods & $\mathrm{MeOH}$ & $285.37 \pm 0.01$ \\
& EtOAc & $173.37 \pm 0.02$ \\
\hline
\end{tabular}

\section{Total flavonoids contents}

In both categories, the total flavonoids contents in seeds were significantly higher than in pods. Comparing the extracts of the same part of plant, it was found that methanolic extracts had higher contents of total flavonoids than ethyl acetate extracts. The result of total flavonoids content is summarized in Table 3. The content of flavonoids $(\mathrm{mg} / \mathrm{g})$, in quercetin equivalents $(\mathrm{Qu} \mathrm{E})$, varied from $5.02 \pm 0.03$ to $66.45 \pm 0.01$. Of the two extracts of each vegetable, the extracts of seeds had the highest flavonoid contents, with that of methanolic extract being the highest $(66.45 \pm$ 0.01).The total content of flavonoids and phenolics are influenced by the interaction between parts of plants (Ghasemzadeh et al., 2010).

Table 3: Total flavonoids contents.

\begin{tabular}{lcc}
\hline Categories & Sample & $\begin{array}{c}\text { Total flavonoids contents } \\
(\mathbf{m g} \text { QuE / g DE) }\end{array}$ \\
\hline \multirow{2}{*}{ Pods } & $\mathrm{MeOH}$ & $22.20 \pm 0.02$ \\
& EtOAc & $5.02 \pm 0.03$ \\
\multirow{2}{*}{ Seeds } & $\mathrm{MeOH}$ & $66.45 \pm 0.01$ \\
& EtOAc & $43.4 \pm 0.02$ \\
\hline
\end{tabular}

\section{Antioxidant studies}

Dietary antioxidants have a dual role: they can prevent food oxidation, in particular lipid oxidation, and at the same time, increase the antioxidant intake from diet. In organism, these exogenous antioxidants can manifest a wide variety of actions, including inhibition of oxidizing enzymes, chelation of transition metals, transfer of hydrogen or a single electron to radicals, singlet oxygen deactivation, or enzymatic detoxification of reactive oxygen species (Morales-González, 2013). Common result of these actions is the protection against degenerative diseases, for example, atherosclerosis, cancer, diabetes, rheumatoid arthritis and inflammatory diseases, which are caused by the increased level of reactive radical species (Prior et al., 2005). Therefore, in order to extensively characterize antioxidant potential of the $C$. villosa subsp. intermedia extracts examined, different antioxidant assays were applied. Examined seeds and pods extracts demonstrated antioxidant potency regarding the reactions based on singleproton/electron transfer (DPPH', FRAP and TAC assays). However, these activities were manifested at moderate intensity in comparison to standard antioxidants butylatedhydroxytoluene (BHT), gallic acid (GA), ascorbic acid (AA) and tannic acid (TA).

\section{Determination of free radical scavenging activity by DPPH method}

The DPPH (1,1-diphenyl-2-picrylhydrazyl) radical scavenging activity is given in Figures 1 and 2 . This activity was increased by increasing the concentration of the sample extract at $518 \mathrm{~nm}$. DPPH antioxidant assay is based on the ability of a potential antioxidant to scavenge the stable radical of 1,1diphenyl-2-picrylhydrazyl (DPPH), a stable free radical contains an odd electron, which is responsible for a strong absorption band in the range of $515-520 \mathrm{~nm}$. In the presence of antioxidant compounds, DPPH can accept an electron or a hydrogen atom from the antioxidant scavenger molecule, to be converted to a more stable DPPH molecule. As the reduced form of DPPH is pale yellow, the greater the free radical scavenging capacity of an antioxidant compounds, is identified by the more reduction of DPPH and the less purple color there is in the sample. The assessment of antioxidant activity showed that the examined seeds were able to scavenge this radical (Figure 1). 


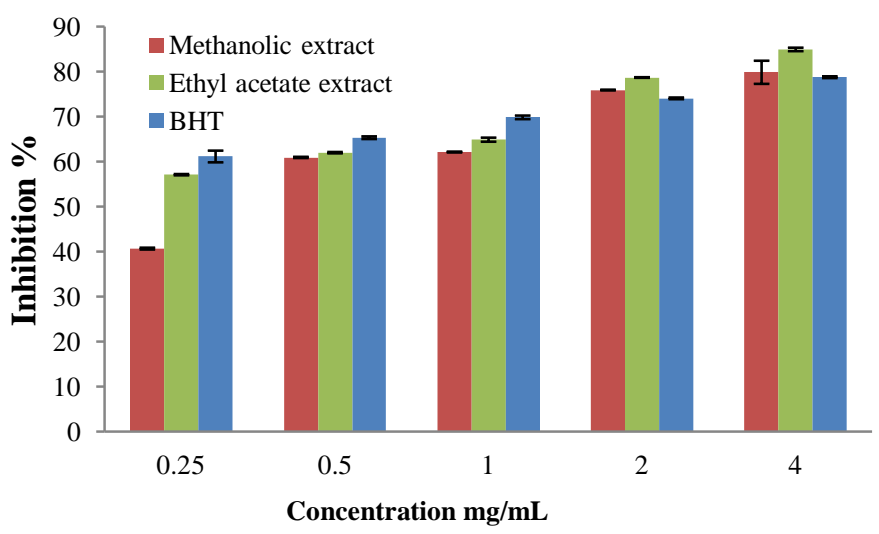

Fig. 1: Antioxidant activities of methanol and ethyl acetate extracts from Calycotome villosa seeds measured by DPPH method. BHT was used as reference antioxidant.

Ethyl acetate extract of seeds showed a high antioxidant activity, being able to scavenge more than $80 \%$ of the DPPH radical at concentration of $4 \mathrm{mg} / \mathrm{mL}$ which displayed the highest activity than methanolic extract $\left(\mathrm{IC}_{50}\right.$ values were: $0.2,0.34$ $\mathrm{mg} / \mathrm{mL}$, respectively). A higher DPPH radical-scavenging activity is associated with a lower $\mathrm{IC}_{50}$ value. Different extracts of pods are shown in Figure 2.

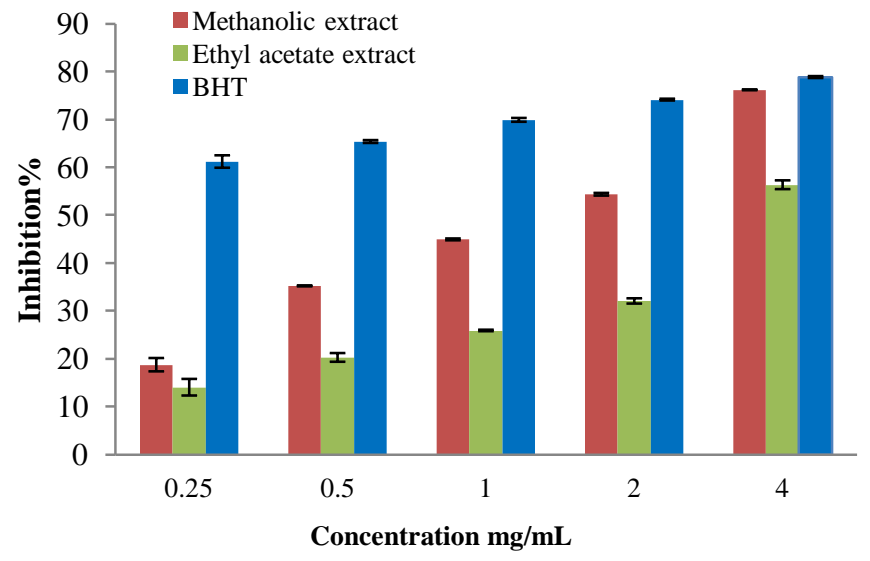

Fig. 2: Antioxidant activities of methanol and ethyl acetate extracts from Calycotome villosa pods measured by DPPH method. BHT was used as reference antioxidant.

Ethyl acetate extract showed very weak DPPH radical scavenging activity, when compared to those reported for methanol extract which were active and able to scavenge $76.15 \pm$ $0.04 \%$ of the DPPH radical at concentration of $4 \mathrm{mg} / \mathrm{mL}$. In the same context, the results of DPPH tests for pods extracts showed that $\mathrm{IC}_{50}$ values obtained for the samples submitted to DPPH assay were in the ranged from 1.53 to $3.5 \mathrm{mg} / \mathrm{mL}$. As mentioned above, this plant contains a number of compounds such as flavones glycosides (El Antri et al., 2004a), flavonols (El Antri et al., 2010), and tannins which were responsible for a higher DPPH radical scavenging activity. In this respect, our results indicate that the seeds and pods of $C$. villosa subsp. intermedia showed high free radical scavenging activity proposing that these parts of plant may be used as a cheap source for natural antioxidants.

\section{Total antioxidant capacity (TAC)}

In the phosphomolybdenum assay, which is a quantitative method to evaluate the antioxidant capacity (Arabshahi-Delouee and Urooj, 2007), all extracts exhibited different degrees of activity as shown in Figures 3 and 4. All crude extracts showed increasing antioxidant activity with increasing concentration. It was, however, observed that the ethyl acetate extract of the seeds possesses significant total antioxidant capacity equivalent to $157.6 \mathrm{mg} / \mathrm{g}$ ascorbic acid at higher concentration (100 $\mu \mathrm{g} / \mathrm{mL})$, and followed by methanolic extract. Gallic acid, as positive control, was found to be less efficiency $(130.88 \mathrm{mg} / \mathrm{g}$ ascorbic acid equivalents) at the same concentration. The crude extracts of pods showed the lowest antioxidant activity.

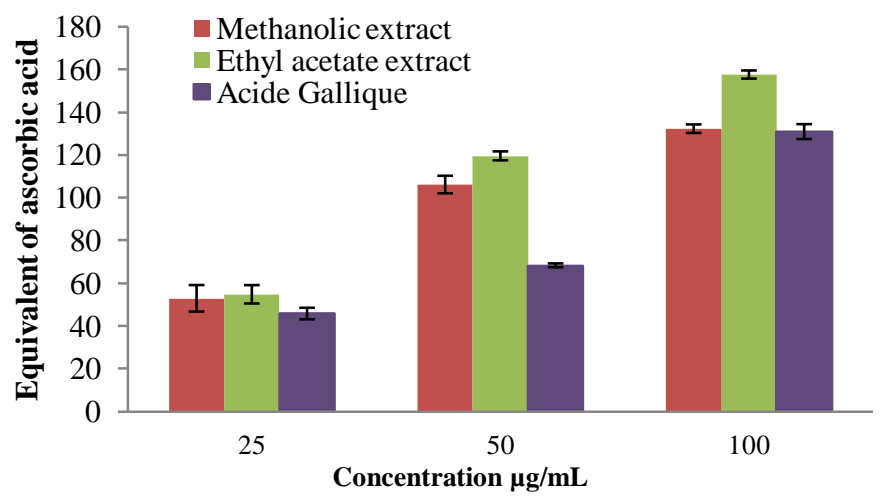

Fig. 3: Total antioxidant activity (TAC) of methanol and ethyl acetate extracts from Calycotome villosa seeds.

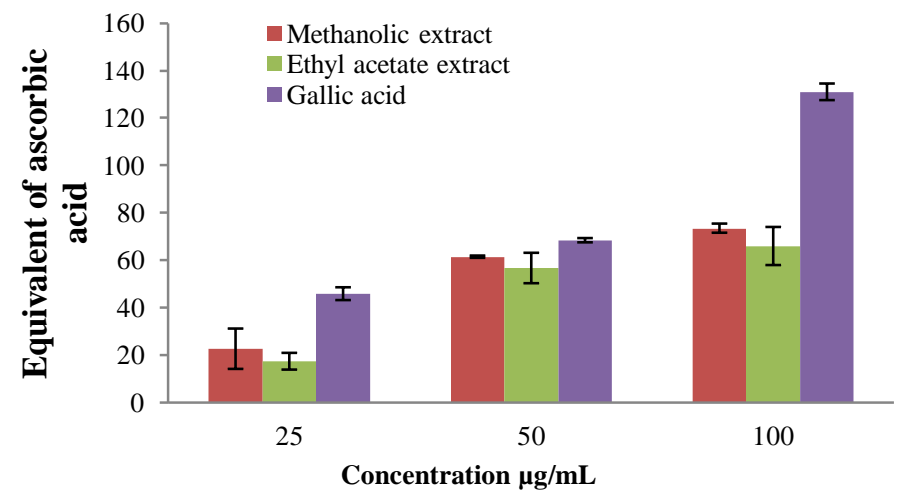

Fig. 4: Total antioxidant activity (TAC) of methanol and ethyl acetate extracts from Calycotome villosa pods.

\section{Ferric reducing antioxidant power (FRAP)}

The antioxidant activity of phenolic compounds is mainly due to their redox properties, which can play an important role in absorbing and neutralizing free radicals, quenching singlet and triplet oxygen, or decomposing peroxides (Osawa, 1994). For the measurements of the reductive ability, it has been found that the $\mathrm{Fe}^{3+}-\mathrm{Fe}^{2+}$ transformation occurred in the presence of extract samples which were postulated previously by Oyaizu (Oyaizu, 1986). Earlier authors (Tanaka et al., 1988) have observed a direct correlation between antioxidant activity and reducing power of certain plant extracts. The reducing properties are generally associated with the presence of reductones (Duh et al., 1999), 
which have been shown to exert antioxidant action by breaking the free radical chain by donating a hydrogen atom (Gordon, 1990). Reductones are also reported to react with certain precursors of peroxide, thus preventing peroxide formation. Figure 5 shows the reductive capabilities of the plant extracts compared to ascorbic acid and to tannic acid.

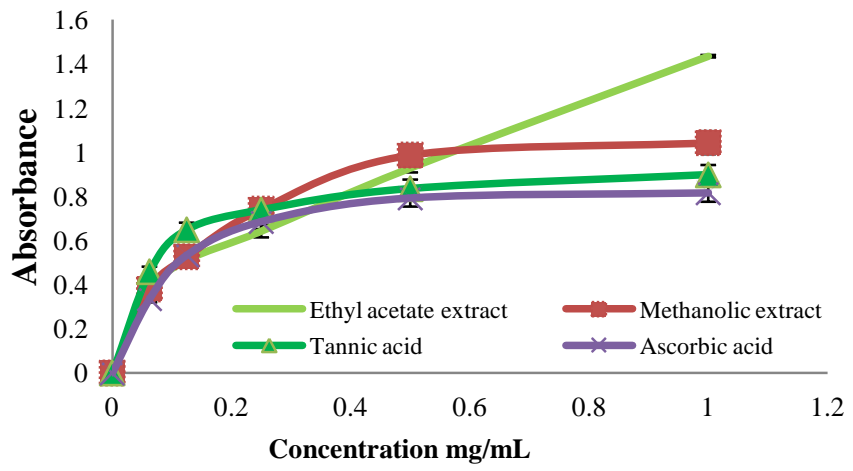

Fig. 5: Reducing power of the crude seeds extracts. Values are the average of duplicate experiments and represented as mean \pm standard deviation.

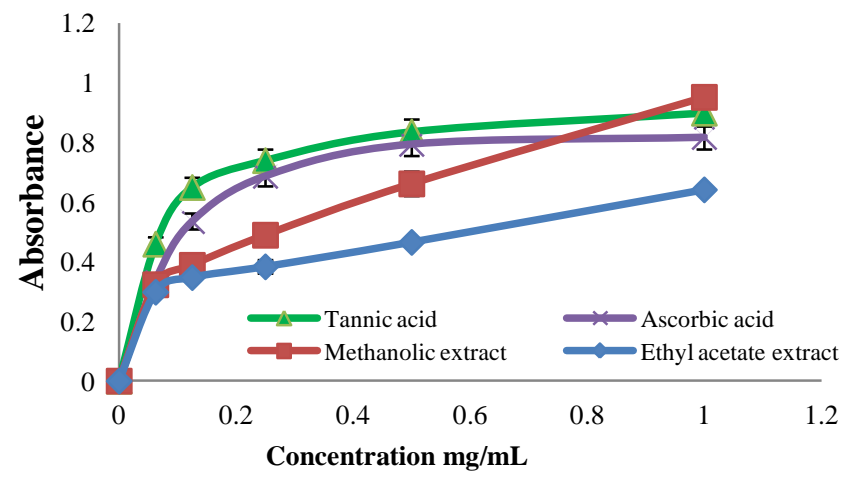

Fig. 6: Reducing power of the crude pods extract. Values are the average of duplicate experiments and represented as mean \pm standard deviation.

The reducing power of the seeds extracts of Calycotome villosa subsp. intermedia was found remarkable indeed the ethyl acetate extract shows a high reducing ability relative to the methanolic extract which is better than ascorbic acid and tannic acid at concentration of $0.32 \mathrm{mg} / \mathrm{mL}$. Figure 6 shows the reducing power of the methanolic extract and ethyl acetate extract of the pods which were less than those of ascorbic acid and tannic acid except for the methanolic extract at concentration of $0.79 \mathrm{mg} / \mathrm{mL}$. The activity was found in the order, methanolic extract > ethyl acetate extract, which was in correlation with the presence of total phenolics and flavonoids content in the respective extracts. The reducing power of the extract was observed to rise as the concentration of the extract was gradually increased. These results suggest that all the extract possess phenols or some other compounds with hydrogen donating ability.

\section{Antibacterial activity}

The results of the antibacterial activity were presented in Table 4. The negative control used (DMSO 2\%) did not exert any inhibition on the strains tested. In the present study, ethyl acetate and methanol extracts of seeds and pods exhibit remarkable antibacterial activity against the strain (Escherichia coli). However, gram positive strains and $P$. aeroginosa tested were resistant to all extracts. Ethyl acetate extract of seeds showed weak inhibition against Bacillus subtilis, whereas its activity toward the other two tested organisms was found to be absent. It is worth noting that all of the extracts showed greater potent antibacterial activity gram negative bacteria, especially Escherchia coli (inhibition zone: $50 \mathrm{~mm}$ ).

Table 4: The growth-inhibitory diameters $(\mathrm{mm})$ of methanol and ethyl acetate extracts of seeds and pods against the tested bacteria.

\begin{tabular}{|c|c|c|c|c|}
\hline \multirow[b]{2}{*}{ Bacterial strains } & \multicolumn{2}{|l|}{ Pods } & \multicolumn{2}{|l|}{ Seeds } \\
\hline & $\begin{array}{l}\text { Ethyl } \\
\text { acetate } \\
\text { extract }\end{array}$ & $\begin{array}{l}\text { Methanol } \\
\text { extract }\end{array}$ & $\begin{array}{l}\text { Ethyl } \\
\text { acetate } \\
\text { extract }\end{array}$ & $\begin{array}{l}\text { Methanol } \\
\text { extract }\end{array}$ \\
\hline $\begin{array}{ll}\text { Escherichia } & \text { coli } \\
\text { ATCC } 25922 & \end{array}$ & $\begin{array}{l}\text { Total } \\
\text { inhibition }\end{array}$ & $\begin{array}{l}\text { Total } \\
\text { inhibition }\end{array}$ & $\begin{array}{l}\text { Total } \\
\text { inhibition }\end{array}$ & $\begin{array}{l}\text { Total } \\
\text { inhibition }\end{array}$ \\
\hline $\begin{array}{l}\text { Pseudomonas } \\
\text { aeroginosa ATCC } \\
27853\end{array}$ & - & - & - & - \\
\hline $\begin{array}{ll}\text { Bacillus } & \text { subtilis } \\
\text { ILP } 14283 & \end{array}$ & - & - & $8 \mathrm{~mm}$ & - \\
\hline $\begin{array}{l}\text { Staphylococcus } \\
\text { aureus } \\
\text { ATCC } 25922\end{array}$ & - & - & - & - \\
\hline
\end{tabular}

Key: - = no antibacterial activity detected.

\section{CONCLUSION}

The results of antioxidant evaluation based on the three models (DPPH, TAC \& FRAP) used in this study revealed that ethyl acetate and methanol extract of Calycotome villosa subsp. intermedia seeds possess interesting antioxidant activity followed by methanol extract of pods. Based on the distribution of metabolites quantified in each of the parts, it can be seen that the values obtained in the seeds of the plant are having a higher antioxidant capacity, particularly those belonging to the ethyl acetate extracts which provide with less content of phenolic compounds and flavonoids, compared to methanolic extract of the same part. The correlation analysis between the values of DPPH, TAC and FRAP indicates the viability of the three models for evaluating antioxidants from medicinal plants. Furthermore, all extracts showed good antibacterial activity against Escherichia coli. Our finding therefore reveals the potentials of Calycotome villosa subsp. intermedia as important source of natural antioxidants which may provide protection against free radicals induced damage to biomolecules.

\section{ACKNOWLEDGMENTS}

\section{Financial support and sponsorship}

This work was funded by the Sidi Mohammed Ben Abdellah University (Fez, Morocco) and the National Center for Scientific and Technical Research (CNRST-Rabat) under grant no. URAC19.

Conflict of Interests: There are no conflicts of interest. 


\section{REFERENCES}

Arabshahi-Delouee S, Urooj A. Antioxidant properties of various solvent extracts of mulberry (Morus indica L.) leaves. Food Chem, 2007; $102: 1233-1240$.

Arvouet-Grand A, Vennat B, Pourrat A, Legret P. Standardisation d'un extrait de propolis et identification des principaux constituants. J Pharm Belg, 1994; 49: 462-468.

Blois MS. Antioxidant determinations by the use of a stable free radical. Nature, 1958; 181: 1199-200.

Bonin G. 1994. Quelques aspects des forêts d'Afrique du Nord, forêt méditerranéenne T. XV $n^{\circ} 1$.

Bondet V, Brand-Williams W, Berset C. Kinetics and mechanisms of antioxidant activity using the DPPH free radical method. LWT - Food Sci Technol, 1997; 30(6): 609-615.

Brand-Williams W, Cuvelier ME, Berset C. Use of a free radical method to evaluate antioxidant activity. LWT - Food Sci Technol, 1995; 28(1): 25-30.

Chen Z, Bertin R, Froldi G. $\mathrm{EC}_{50}$ estimation of antioxidant activity in DPPH assay using several statistical programs. Food Chem, 2013; 138(1): 414-420.

De S, Dey YN, Ghosh AK. Phytochemical investigation and chromatographic evaluation of different extracts of tuber of Amorphaphallus paeoniiflius (Araceae). Int J pharm Biomed Res, 2010; 1(5): 150-157.

Duh PD, Tu YY, Yen GC. Antioxidant activity of the aqueous extract of harn jyur (Chrysanthemum morifolium Ramat). Lebensm. Wiss Technol, 1999; 32: 269-277.

El antri A, Messouri I, Chendid Tlemcani R, Bouktaib M, El Alami R, El Bali B, Lachkar M. Flavone glycosides from Calycotome villosa subsp. intermedia. Molecules, 2004a; 9: 568-573.

El Antri A, Messouri I, Bouktaib M, El Alami R, Bolte M, El Bali B, Lachkar M. Isolation and X-ray crystal structure of tetrahydroisoquinoline alkaloids from Calycotome villosa subsp. intermedia. Molecules, 2004b; 9: 650-657.

El Antri A, Messouri I, Bouktaib M, El Alami R, Bolte M, El Bali B, Lachkar M. Isolation and X-ray crystal structure of a new isoquinoline-N-oxide alkaloid from Calycotome villosa subsp. intermedia. Fitoterapia, 2004c; 75: 774-778.

El Antri A, Lachkar N, El Hajaji H, Gaamoussi F, Lyoussi B, El Bali B, Morel N, Allouchi H, Lachkar M. Structure elucidation and vasodilator activity of methoxy flavonols from Calycotome villosa subsp. intermedia. Arabian J Chem, 2010; 3: 173-178.

Elkhamlichi A, El Antri A, El Hajaji H, El Bali B, Oulyadi H, Lachkar M. Phytochemical constituents from the seeds of Calycotome villosa subsp. intermedia. Arabian J Chem, 2014; doi:10.1016/j.arabjc.2014.03.005.

Espina L, Somolinos M, Lorán S, Conchello P, García D, Pagán R.. Chemical composition of commercial citrus fruit essential oils and evaluation of their antimicrobial activity acting alone or in combined processes. Food Control, 2011; 22(6): 896-902.

Ghasemzadeh A, Jaafar HZ E, Rahmat A. Antioxidant Activities, Total Phenolics and Flavonoids Content in Two Varieties of Malaysia Young Ginger (Zingiber officinale Roscoe). Molecules, 2010; 15: 4324-4333.

Gibbs PE. Taxonomy and distribution of the genus Calicotome. Notes Roy Bot Gard, 1968; 28: 275-286.

Gordon MH. 1990. The mechanism of antioxidant action in vitro, in: Hudson BJF, Ed. Food antioxidants. Elsevier Applied Science, London, pp. 1-18.

Greuter W, Burdet HM, Long G. 1989. A critical inventory of vascular plants of the circum-mediterranean countries. Dicotyledones (Lauraceae-Rhamnaceae). Geneva, Switzerland, Med-Checklist 4.

Harborne JB. 1999. Classes and functions of secondary products from plants. In: Walton JN, Brown DE, editors. Chemicals from plants: perspectives on plant secondary products. London, UK: Imperial College Press. pp. 1-25.
Hartwell JL. 1982. Plants used against Cancer. A survey. Lawrence, M.A., USA7 Quarterman Publications.

Kedare SB, Singh RP. Genesis and development of DPPH method of antioxidant assay. J Food Sci, 2011; 48(4): 412-422.

King A, Young G. Characteristics and occurrence of phenolic phytochemicals. J Am Diet Assoc, 1999; 99: 213-218.

Lentini F, Aleo M, Amenta R. L'uso popolare delle piantenelle Isole Egadi (Sicilia). Giorn Bot Ital, 1993; 127 (3): p.702.

Miliauskas G, Venskutonis PR, Van Beek TA. Screening of radical scavenging activity of some medicinal and aromatic plant extracts. Food Chem, 2004; 85: 231-237.

Molyneux P. The use of the stable free radical diphenylpicrylhydrazyl (DPPH) for estimating antioxidant activity. Songklanakarin J Sci Technol, 2004; 26(2): 211-219.

Morales-González JA. 2013. Oxidative stress and chronic degenerative diseases-a role for antioxidants, Edition: 1, Publisher: INTECH, Editor: José A. Morales González.

NCCLS. 2012. Performance Standards for Antimicrobial Disk Susceptibility Tests; Approved Standard-Eleventh Edition. CLSI document M02 A11 Wayne, PA; Clinical and laboratory standards institute.

Osawa T. 1994. Novel natural antioxidants for utilization in food and biological systems. In: Uritani I, Garcia VV, Mendoza E.M. (Eds) Post harvest biochemistry of plant food-materials in the tropics. Japan Scientific Societies Press, Japan. pp. 241-251.

Oyaizu M. Studies on product of browning reaction prepared from glucose amine. Jpn J Nutr, 1986; 44: 307-315.

Perez-Jimenez J, Arranz S, Tabernero M, Díaz-Rubio ME, Serrano J, Goñi I, Saura-Calixto F. Updated methodology to determine antioxidant capacity in plant foods, oils and beverages: extraction, measurement and expression of results. Food Res Int, 2008; 41(3): 274285.

Prieto P, Pineda M, Aguilar M. Spectrophotometric quantitation of antioxidant capacity through the formation of a phosphomolybdenum complex: Specific application to the determination of vitamin E. Anal Biochem, 1999; 269: 337-341.

Prior R, Wu X, Schaich K. Standardized Methods for the Determination of Antioxidant Capacity and Phenolics in Foods and Dietary Supplements. J Agric Food Chem, 2005; 53: 4290-4302.

Rice-Evans CA, Miller NJ, Paganga G. Structure-antioxidant activity relationships of flavonoids and phenolic acids. Free Radic Biol Med, 1996; 20: 933-956.

Singleton VL, Rossi JA. Colorimetry of total phenolics with phosphomolybdic-phosphotungstic acid reagents. Am J Enol Vitic, 1965; 16: $144-158$.

Slinkard K, Singleton VL. Total phenol analysis: automation and comparison with manual methods. Am J Enol Vitic, 1977; 28: 49-55.

Tanaka M, Kuie CW, Nagashima Y, Taguchi T. Applications of antioxidative Maillard reaction products from histidine and glucose to sardine products. Nippon Suisan Gakk, 1988; 54: 1409-1414.

Tutin GT. 1972. Flora Europea. University Press, Cambridge.

Viturro C, Molina A, Schmeda-Hischmann G. Free radical scavengers from Mutisia friesiana (Asteraceae) and Sanicula graveolens (Apiaceae). Phytother Res, 1999; 13: 422-424.

\section{How to cite this article:}

Elkhamlichi A, El-Hajaji H, Faraj H, Alami A, El-Bali B, Lachkar M. Phytochemical screening and evaluation of antioxidant and antibacterial activities of seeds and pods extracts of Calycotome villosa subsp. Intermedia. J App Pharm Sci, 2017; 7 (04): 192-198. 